\title{
Students' Assessment of Hostel Facilities in The Polytechnic Ibadan, Nigeria: Realities and Challenges
}

\author{
Olusegun Peter Akinpelu ${ }^{1 *}$, Kehinde Alabukun Oyewole ${ }^{2}$ and Muhydeen Adedeji Owolabi ${ }^{3}$ \\ 1. College of Environmental Sciences, Bells University of Technology, P.M.B. 1015, Ota, Nigeria \\ 2. College of Environmental Sciences, Bells University of Technology, P.M.B. 1015, Ota, Nigeria \\ 3. College of Environmental Sciences, Bells University of Technology, P.M.B. 1015, Ota, Nigeria
}

\begin{abstract}
Provision of on-campus accommodation for students influences students' academic performance and social integration. In order to ensure that students' hostels in tertiary institutions particularly in Nigeria justify this assertion, there is a need to deal with facilities gaps in students' housing. This study examines the status of students' hostel facilities in The Polytechnic, Ibadan, Nigeria, with a view to recognizing the improvement for satisfactory housing for students in tertiary institutions. Using questionnaire, 2 (two) hostels representing half of the total hostels were purposively selected. Subsequently, 101 representing twenty percent $(20 \%)$ of the total population were systematically sampled from the selected hostels. The data obtained from the survey were analyzed using descriptive analysis such as frequency distribution to assess the general level of student' housing facilities and second, to determine the status of hostel facilities. The results of the analysis indicate gross inadequacy of students' housing facilities as a result of non-provision, obsolescence, and inadequate maintenance. It was equally observed that some of the facilities are not evenly distributed. However, the results also revealed adequacy of few facilities. It is recommended that improvement be made on those facilities that were not adequate, while those considered to be adequate should be maintained and sustained by the authorities concerned.
\end{abstract}

Keywords: Student, Hostel, Facility, Polytechnic, Adequacy, Inadequacy and Nigeria

DOI: $10.7176 / \mathrm{JEP} / 10-30-10$

Publication date:October $31^{\text {st }} 2019$

\section{Introduction}

Housing is one of the three basic needs of mankind. After the provision of food, it is most important factor for the physical survival of man. This is particularly true of a special category of individuals students, especially those in tertiary institutions, which requires good accommodation for proper assimilation of what they have been taught (Agbola, 2001). Its availability is fundamental to living in dignity and to good health, good quality of life and general well-being. In spite of this inseparable link between good housing and health, over 100 million people worldwide are homeless, while more than a billion live in shelters that are not only inadequate but are also detrimental to health (Godshall, 2000). Adeniyi (1974) observed that the availability of adequate housing, either in single or multiple units, is a significant component of the physical form and structure of a community.

From available information, student accommodation in tertiary institutions in Nigeria is severely overcrowded. The main cause of this perennial problem is the increasing number of students being admitted, without a commensurate increase in the number of hostel facilities (Agbola et al., 2001). This situation has been aggravated by the scarcity of affordable and safe alternative housing in the neighbourhoods surrounding the institution. The works of Adegbile (1987) and Adelaja (1992) indicate that, on the average, the occupancy ratio has increased by 300 per cent, that is, fourteen persons are occupying rooms designed for four persons. Adelaja stated further that some of the existing furniture has been removed in order to provide space for additional double bunks. Most of the few facilities that presently exist in Nigerian institutions' hostels are the built-in-type. Consequently, most students have to study somewhere else, due to the uncomfortable nature of their residences.

However, it has been established that housing has a profound influence on the health, efficiency, social behaviour, satisfaction and general welfare (Onibokun, 1985). With this, it means that housing exerts influence on overall performance of its residents. Students need comfortable accommodation for them to have a conducive environment for their primary function in their institutions (Osagie, 1993). Nevertheless, original idea of students' housing was to provide a more conducive academic atmosphere for students. As a result, the first generation tertiary institutions built hostels, befitting the image of undergraduate students. Students' population then was within control (Egwunyenga, 2009). Presently, the situation of hostel is opposite of what it used to be, as a result of sporadic increase in number of prospective candidates seeking admission into Nigeria tertiary 
institutions. This phenomenon has made hostels lose its original purpose of providing conducive academic atmosphere, good for learning and social integration. The combined effects of these are increased pressure on utilities such as water, the frequent breakdown of the sewage disposal system and the unsanitary condition of some of the halls of residence. This ugly situation in tertiary institutions necessitated the need to assess the facilities gap, so as to make recommendations for improvement. It is against this background that this study assessed the adequacy of facilities in students' hostels in The Polytechnic, Ibadan, Nigeria.

\section{Theoretical issues}

In broad term, housing is defined by Bourne (1981) as a bundle of services, a view which recognizes that housing involves the consumption of neighbourhood services that is, parks and schools, a location (accessibility to job and amenities), and the proximity of certain types of neighbors (a social environment). Housing is a highly complex product as well as a facilitator of economic and social processes. With reference to the former, the PRC Report (1980) observes that it comprises shelter (for protection and privacy), environmental services (water supply, waste disposal, etc), access to employment opportunities (such as commercial activities), personal security (for safety), special services (such as health care and education) and living space (for recreation and domestic activities). In line with the latter conception of housing, Turner (1976) describes housing as the ways and means by which housing goods and services are provided by human actions through housing construction or investment in order for housing to confer the various benefits and provide different facilities for users, the individual, households and the nation.

Student on-campus housing can equally be described as a process in the sense that it involves the construction of new dwellings and the various associated activities such as land acquisition, finance, building materials, etc. As an asset, students' on-campus housing form the bulk of the higher institutions built environment thereby representing the largest facility asset that an institution may have (Amole, 1997). Thus, student on-campus housing is not only shelter, but comprises the immediate environment and other economic and social activities that are sympathetic to academic work. Many scholars hold the belief that there should be close proximity between the living and learning environment in order to produce intellectuals that are socially integrated (Amole, 1997).

One of the major factors behind student accommodation problems all over the world is the ever increasing number of students. In London, for instance, Tabet (1971) reported that traditional halls of residence have been provided in considerable numbers but they have not kept pace with the growth of the student population. The situation was not different in the rest of England and Wales. According to Morgan and McDowell (1979), it would appear that the provision of accommodation in all sectors of higher education the expansion of the student population. This is because majority of students study far away from home. For most students going away to higher institution is their first real introduction to adult social life, free from the constraints of parental control, neighbourhood and family ties. It was therefore, the opinion of these scholars that the significance and educational benefits attached to on-campus residence have reinforced the increasing common practice among students to study away from home.

In Nigeria, a prototype of a developing country, the case is not different. The work of Ohiagbunem (1984) indicated that the problem of student population and shortage of funds, the student population continues to grow without a corresponding growth in hostel facilities.

\section{The Study area}

\subsection{The Polytechnic, Ibadan}

The study area is located at the centre of city of Ibadan, western Nigeria on latitude 7.23 north of the Equator and longitude 3.56 east of Greenwich Meridian Dada, et al (2007). The location of the institution is shown in figure 1. 


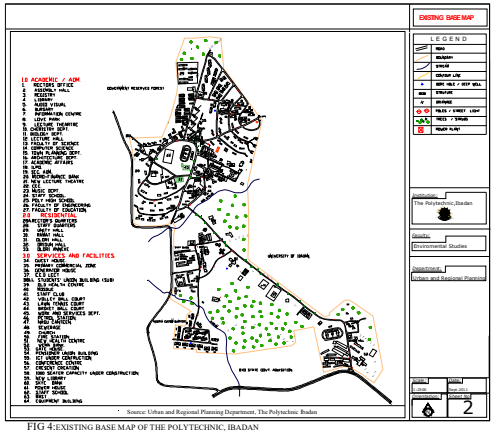

It is situated in Ibadan North Local Government Area of Oyo State. The Polytechnic, Ibadan was established in 1970 as a successor to the erstwhile Technical College, Ibadan under the provisions of a principal Edict cited as the Polytechnic, Ibadan Edict 1970. This Edict has undergone several amendments in order to make the Polytechnic relevant to the present day needs of Oyo State, the Proprietor.

The primary function of the Polytechnic is to provide for students training and development of techniques in applied sciences, engineering, environmental sciences and commerce. The Polytechnic has been producing majorly middle level manpower that has been making valuable contributions to the social and economic development of the country.

The Polytechnic, Ibadan main campus is primarily residential with halls of residence for both male and female students. The names of the halls with their capacity are as follows:

Table 1.2 Halls of residence in The Polytechnic, Ibadan

\begin{tabular}{llllllll}
\hline S/N & Halls & Gender & $\begin{array}{l}\text { Academic } \\
\text { Level }\end{array}$ & $\begin{array}{l}\text { No of } \\
\text { Blocks }\end{array}$ & $\begin{array}{l}\text { No of } \\
\text { Rooms }\end{array}$ & $\begin{array}{l}\text { No of Bed } \\
\text { spaces }\end{array}$ & $\begin{array}{l}\text { Year of } \\
\text { Construction }\end{array}$ \\
\hline 1 & Olori & Female & OND/HND & 7 & 309 & 639 & 1971 \\
2 & Orisun & Mixed & OND/HND & 5 & 200 & 800 & 1980 \\
3 & Ramaat & Female & OND/HND & 4 & 156 & 313 & 1971 \\
4 & Unity & Male & OND/HND & 6 & 192 & 715 & 1980 \\
\multicolumn{1}{l}{ Total } & & & & 22 & 857 & 2,467 & \\
\hline
\end{tabular}

3.1.1 Olori hall is an OND and HND female hall. It was built in 1971, with a capacity of 639 students. The hall consists of seven blocks lettered A to G. Each of the blocks has three floors, with fourteen rooms in each floor. Block C, D and E have basement, each contains five rooms. Two students are allocated to each room and the size of the room is $3.0 \mathrm{~m} \times 2.0 \mathrm{~m}$. Rooms are cross ventilated, one door and in each rooms is a reading table and chair, one wardrobe and no bunk. Each of the floors has a kitchen, three bathrooms and toilets attached to it. Available open spaces are not organized, but flowers are planted in front of some of the blocks. Provision is made for common room, reading room, supervisor's office, porter's lodge and a store within the hall.

3.1.2 Orisun hall is a mixed OND and HND hall. It was built in 1980, with a capacity of 800 students. The hall consists of five blocks lettered A to E. Blocks A and B is meant for female OND and HND students. These blocks have three floors each and each of the floors consists of twelve rooms, having four students per room. Six kitchenettes, bathrooms and toilets are attached to each floor. Blocks C, D, and E are reserved for male OND and HND students. Block $\mathrm{C}$ has four floors with thirty two rooms. Each of the floors consists of eight rooms and four students are accommodated per room. Eight Kitchenettes, six bathrooms and toilets are attached to each floor. While, blocks D and E have four floors each, with twelve rooms in each floor. Four students are accommodated per room. Twelve kitchenettes, six bathrooms and toilets are attached to each floor. Each room accommodates four students. Rooms are cross-ventilated with two doors and in each room are four wardrobes and no bunks. Available open spaces are not organized, but rows of flowers are planted in front of some blocks. 
3.1.3 Ramaat hall is an OND and HND female hall. It was built in 1971, with a capacity of 313 students. The hall consists of four blocks, lettered A, B, C and D. Each of the blocks has three floors with thirteen rooms in each. Two students are allocated to each rooms and the size of each room is $3.0 \mathrm{~m} \times 2.0 \mathrm{~m}$. Rooms are cross ventilated, one door and in each rooms is a reading table and chair, one wardrobe and no bunk. Each of the floors has a kitchen, three bathrooms and toilets attached to it. Available opens spaces within the hall are not organized, but flowers are planted in front of some of the blocks. Provision is made for common room, reading room, supervisor's office, porter's lodge and a store within the hall.

3.1.4 Unity hall is an OND and HND male hall. It was built in 1980, with a capacity of 715 students. The hall consists of six blacks, lettered A to F. Each of the blocks has four floors with eight rooms in each. Four students are allocated to each room and the size of each room is $4.0 \mathrm{~m} \times 3.5 \mathrm{~m}$. Rooms are cross ventilated, one door, and in each of the room are four chairs and reading tables, four wardrobes and single bunk. Each of the floors has a kitchen, five bathrooms and four toilets attached to it. Available open spaces within the hall are not organized, but flowers are planted in front of some of the blocks. Provision is made for common room, reading room, supervisor's office, porter's lodge and a store within the hall.

\section{Methodology}

This section discusses the methodology used in this study. Descriptive statistics was utilised for analyse the data collected for this study.

\section{a. Hostels sampled for questionnaire administration}

\begin{tabular}{lllll}
\hline Institutions & Halls & Rooms & Sample Size & Percentage \\
\hline The Polytechnic, Ibadan & Olori & 304 & 60 & 20 \\
& Unity & 192 & 40 & 20 \\
& Total & 501 & 101 & 20 \\
\hline
\end{tabular}

The primary data were sourced through reconnaissance survey. This became relevant in order to have a clear focus of the study and ensure effective planning of the research exercise. Also, direct observation, personal interviews and structured questionnaires were employed to gather other relevant data from students that were residing in hostels on existing hostel facilities.

Purposively, two hostels representing half of the total hostels were selected. Questionnaires were administered to a student in one of every 5th rooms in each of the hostels' block. Subsequently, 101 representing twenty per cent $(20 \%)$ of the total population were systematically sampled from the selected hostels. The data collected were analysed using descriptive statistics.

\section{Results and Discussion}

The research findings are presented under two sub-headings. Unless otherwise stated, tables presented in this section emanated from the field survey of 2012.

\subsection{Evaluation of existing facilities available in the hostels}

Hostels' facilities evaluated are in two categories. One, facilities within the rooms and blocks of each hostel, such as bathrooms, reading chair and table, toilets, etc., and two, facilities within the hostels including: cafeteria, common/TV rooms, cyber café, etc. Information presented in table 5.1, indicated that from a total of 101 students sampled for the purpose of study, all the students claimed to have bathrooms in their hostels and this is true as observed by the researcher during preliminary survey. The proportion $(70.3 \%)$ of students that have reading chair and table in their rooms is high compare to those that do not have $(29.7 \%)$. This might partly due to the fact that reading chair and table are considered to aid studying, because lying down on mattress or sitting on other objects may not be all that comfortable for effective reading. 
Table 5.1: Evaluation of existing facilities available in hostels

\begin{tabular}{llll}
\hline Facilities & Available & Non-Available & Total \\
\hline Bathrooms & $101(100 \%)$ & $0(0.0 \%)$ & $101(100 \%)$ \\
Reading Chair \& Table & $71(70.3 \%)$ & $30(29.7 \%)$ & $101(100 \%)$ \\
Shelf & $22(21.8 \%)$ & $79(78.2 \%)$ & $101(100 \%)$ \\
Toilets & $101(100 \%)$ & $0(0.0 \%)$ & $101(100 \%)$ \\
Wardrobe & $85(84.2 \%)$ & $16(15.8 \%)$ & $101(100 \%)$ \\
Kitchenettes & $32(31.7 \%)$ & $69(68.3 \%)$ & $101(100 \%)$ \\
Cafeteria & $25(24.8 \%)$ & $76(75.2 \%)$ & $101(100 \%)$ \\
Common/TV Room & $79(78.2 \%)$ & $22(21.8 \%)$ & $101(100 \%)$ \\
Cyber Cafe & $52(51.5 \%)$ & $49(48.5 \%)$ & $101(100 \%)$ \\
Reading Room & $87(86.1 \%)$ & $14(13.9 \%)$ & $101(100 \%)$ \\
Recreation Facilities & $22(21.8 \%)$ & $79(78.2 \%)$ & $101(100 \%)$ \\
Waste Disposal Facilities & $23(22.8 \%)$ & $77(76.2 \%)$ & $101(100 \%)$ \\
\hline
\end{tabular}

As seen from the table, $21.8 \%$ of the students affirmed to have shelves in their rooms, while majority $(78.2 \%)$ asserted non existence of the facility.

On the other hand, all the students confirmed to have toilets in their hostels, which emphasizes the importance of this facility in any human community, though some of them were poorly maintained. More than $80 \%$ of the students claimed to have wardrobe in their rooms, while only $15.8 \%$ did not have as at the time of survey. Kitchenettes were only present in few of blocks (31.7\%), despite the fact that its availability would allow students to have more free space within their rooms as food stuff and other items can be kept in the Kitchenette. In addition, only $24.8 \%$ of the students interviewed affirmed to have cafeteria, while $75.2 \%$ of them did not have as at the time of this survey. Common/TV rooms were available in majority $(78.2 \%)$ of the blocks surveyed. Only $52 / 101(51.5 \%)$ of the students have access to cyber café within their hostels, while $48.5 \%$ did not, as at the time of this survey. Virtually, all the blocks surveyed $87 / 101(86.1 \%)$ had reading room. The study area is poorly equipped with recreation facilities, which is evident from the table as 79/101 (78.2\%) of the students claimed not to have. Waste disposal facilities were insufficiently distributed in the study area as $77 / 101(76.2 \%)$ of the students affirmed its absence.

\subsection{Status of selected indices}

Hostel facilities which are found in the literature to be significantly related to housing adequacy include: wardrobe, reading chair and table ( $\mathrm{Li}, 2009)$, kitchenettes, bathroom and toilet (Amole, 2009), recreation facilities (Thomson, 2008).

Table 5.2: Status of selected indices

\begin{tabular}{llll}
\hline Indices & Adequate (\%) & Inadequate (\%) & Total \\
\hline Bathrooms & $40(39.6 \%)$ & $61(50.4 \%)$ & $101(100 \%)$ \\
Reading Chair \& Table & $65(64.4 \%)$ & $36(35.6 \%)$ & $101(100 \%)$ \\
Shelf & $20(19.8 \%)$ & $81(80.2 \%)$ & $101(100 \%)$ \\
Toilets & $30(29.7 \%)$ & $71(70.3 \%)$ & $101(100 \%)$ \\
Wardrobe & $62(61.4 \%)$ & $39(38.6 \%)$ & $101(100 \%)$ \\
Kitchenettes & $20(19.8 \%)$ & $81(80.2 \%)$ & $101(100 \%)$ \\
Cafeteria & $22(21.8 \%)$ & $79(78.2 \%)$ & $101(100 \%)$ \\
Common/TV Room & $54(53.5 \%)$ & $47(46.5 \%)$ & $101(100 \%)$ \\
Cyber Cafe & $45(44.6 \%)$ & $56(55.4 \%)$ & $101(100 \%)$ \\
Reading Room & $63(62.4 \%)$ & $38(37.6 \%)$ & $101(100 \%)$ \\
Recreation Facilities & $19(18.8 \%)$ & $82(81.2 \%)$ & $101(100 \%)$ \\
Waste Disposal Facilities & $25(24.8 \%)$ & $76(75.2 \%)$ & $101(100 \%)$ \\
\hline
\end{tabular}

These identified variables and some others considered to be essential are used to assess adequacy of the students' hostel in the study area.

Despite the fact that all the rooms within the hostels were served with bathrooms, however most of the bathrooms were in deplorable conditions. This might be the reason why $61 / 101(60.4 \%)$ asserted to its 
inadequacy. Reading chairs and tables were found to be adequate as revealed in Table 5.2. Though few (29.7\%) of the rooms did not have the facility as at the time of survey, still most of the students agreed to its sufficiency. Oral information gathered from students confirmed that every room was provided with reading chairs and tables, but some rooms in the hostels are no more having because of activities of students that can be regarded as vandals, conversely the provision was considered as being adequate. Majority $(80.2 \%)$ of the students authenticated inadequacy of shelf in their rooms. This substantiates the mainstream responses to its non availability virtually in all the rooms as evident in Table 5.1. Though, all the students affirmed the existence of toilets in their hostels, yet they were still regarded as inadequate, probably because of poor maintenance, which make some of them unhygienic.

Wardrobes were considered to be adequate by most of the students surveyed (see Plate 1). Nearly, all rooms surveyed have wardrobes big enough to contain their clothes. Others who disagreed to its inadequacy may be due to the fact that the one in their rooms were in a state of disrepair. As evident in Table 5.1, majority $(68.3 \%)$ of the student asserted non availability of kitchenette in their hostels. This was corroborated by the responses of $80.2 \%$ of students confirming its inadequacy.

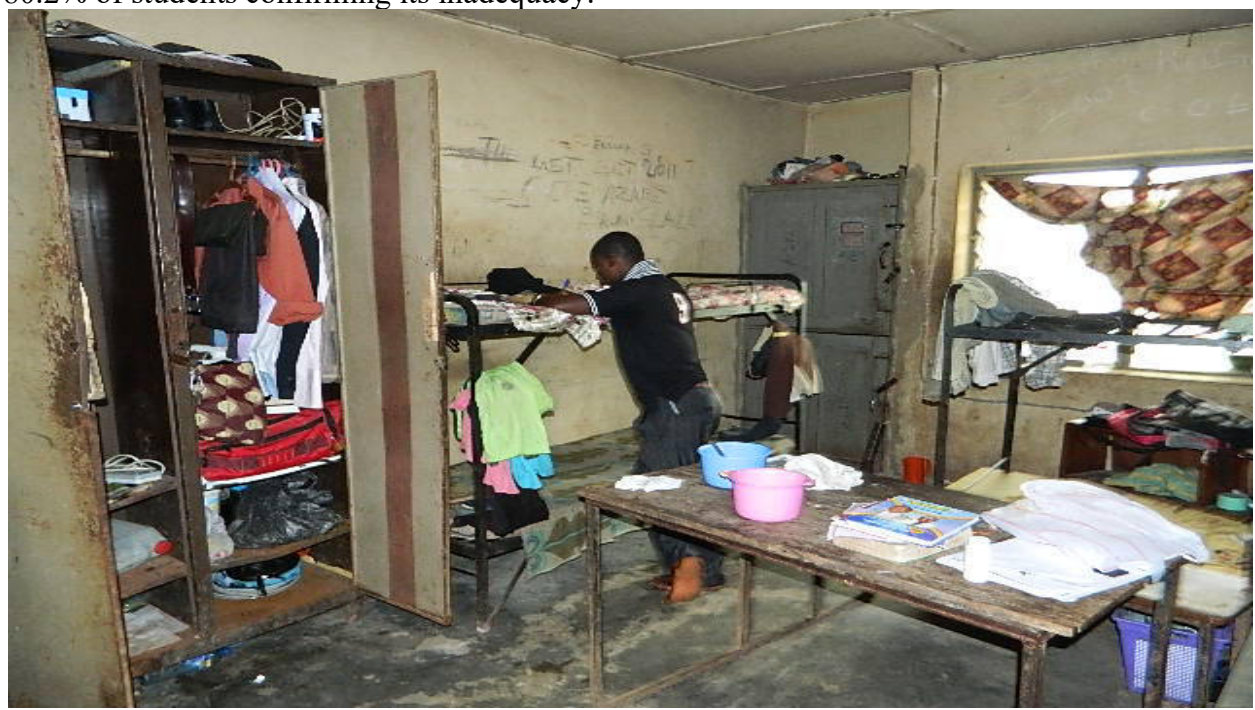

Plate 1: One of the room in the studied hostels with wardrobe, bunks and table

Equally, cafeterias were not sufficiently provided in most of the hostels with reference to Table 5.1, as a result a small number of the students agreed to its adequacy, possibly because of proximity of cafeterias to their hostels. In spite of this, majority (78.2\%) authenticated its inadequacy. With regard to common/TV room 54/101 (53.5\%) of the students validated its adequacy, while 47/101 (46.5\%) disagreed, undoubtedly because of poor maintenance of the room and the facilities in it. Responses of most of the students affirmed inadequacy of cyber café, notwithstanding other students admitted that it is adequate, most likely because of its availability in their hostels or closeness of their hostels to location of cyber café.

The assertion of many of the students surveyed in relation to reading room is that, it was adequate. Though few of them objected to this assertion, doubtless, since their reading rooms did not contain enough reading chairs and tables and the space provided is relatively small compare to the number of users. Students' assessment of recreation facilities can be said to be grossly inadequate. Of 101 students surveyed $82(81.2 \%)$ affirmed that recreation facilities were inadequate (see Plate 2), while some fraction of them (18.8\%) approved its adequacy. This may be due to the proximity of the hostels to sport facilities. Waste disposal facilities were equally assessed to be inadequate by 


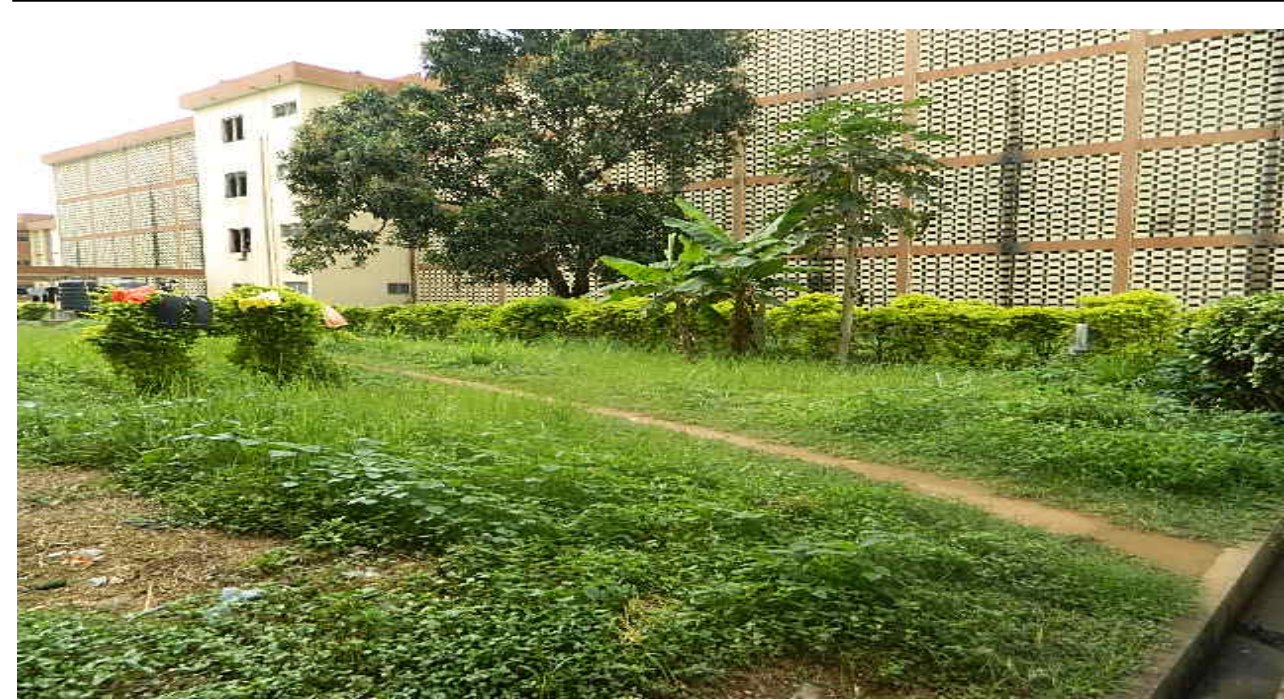

Plate 2: One of the hostels lacking recreation facilities

the majority $(75.2 \%)$ of the students interviewed. However, few of them refuted this affirmation, probably because of availability of the facilities in their hostels or blocks. Another reason may be as a result of the location of their blocks or hostels close to public contact, more attention may be given to the cleanliness of such blocks or hostels to portray good image of school hostels.

\begin{tabular}{|c|c|c|}
\hline \multicolumn{3}{|c|}{ ssessment of hostels' facilities } \\
\hline Status & Number of Indices & Percentage \\
\hline Adequate & 4 & $33.3 \%$ \\
\hline Inadequate & 8 & $66.7 \%$ \\
\hline Total & 12 & $100 \%$ \\
\hline
\end{tabular}

The assessment of the housing facilities in the study area revealed unimpressive conditions under which students live. Hostels' statuses are generally believed to be poor in many tertiary institutions in Nigeria. From overall assessment as seen from the table above, out of twelve indices used to measured hostels' facilities in the study area, $4(33.3 \%)$ were observed to be adequate as at the time of survey, which include: reading chairs and tables, wardrobe, common/TV rooms and reading rooms. However, 8 (66.7\%) were inadequate as confirmed by the students, among them are bathrooms, shelves, toilets, kitchenettes, cafeterias, cyber café, recreation facilities and waste disposal facilities. This finding is in line with the study carried out by Akinpelu (2012) on students' housing satisfaction, where he established that there were gross inadequate of bathrooms and toilets in the study areas. This is a pointer to the fact that there is a need for improvement on the state of facilities in students' hostel in the study area, so as to create a conducive environment which is good for learning and social integration.

\section{Conclusion}

The study has attempted to assess the status of hostel's facilities in The Polytechnic, Ibadan, Nigeria. It was discovered that some facilities were in deplorable conditions, while some were grossly absent, others were not sufficiently provided. Notwithstanding, few facilities were found to be adequate in the study area. However, the proprietor and the institution's authority need to improve on the status of facilities that were inadequate, while efforts should be made to maintain and sustain those ones that were found to be adequate.

\section{Acknowledgements}

The author thanks the management of University of Ibadan and The Polytechnic Ibadan, Nigeria for their support and cooperation during the period of data collection. Also, appreciated are hall wardens, supervisor and porters in each of the institution surveyed. 
References

Adegbile, M.B.O. (1987): Student Reaction in four Halls of Residence. A Seminar Paper Submitted to the Department of Architecture. Obafemi Awolowo University, Ile-Ife.

Adelaja, A.A. (1992): Student Housing Problem. A Seminar Paper Presented to the Department of Architecture, Obafemi Awolowo University, Ile-Ife.

Adeniyi, E.O. (1974): The Provision of Housing. A Challenge to Urban Planning and Development in Africa. Wiser Publication. Lagos.

Agbola, T., Olatubara, C. O. and Alabi, M. (2001): Student On- Campus Housing at Bursting Point: $A$ Case Study of University of Ibadan, Occasional Publication No. 14, pp. 7-10.

Akinpelu, O.P. (2012): Students' Housing Satisfaction in Selected Tertiary Institutions in Oyo State Nigeria. M.Sc. Thesis submitted to Obafemi Awolowo University, Ile-Ife, Nigeria.

Amole, B. (1988): "Location and Quality of Study Places in a University Campus Environment". Odu: $A$ Journal of West African Studies, No. 33.

Amole, D. (1997): “An Evaluation of Students Residential Facilities in Some Nigeria Universities". Unpublished PhD Thesis.Department of Architecture, Obafemi Awolowo University, Ile Ife, Nigeria.

Bourne, L. S. (1981): Geography of Housing. Edward Arnold, London.

Browne, B. A., Kaldenberg, D. O., Browne, W. G., and Brown, D. J. (1998): Student as Customer: Factors Affecting Satisfaction and Assessments of Institutional Quality. Journal of Marketing for Higher Education, 8(3), 1-14.

Dada, O. A. and Garba, M. J., and Adanne, I. (2007): Macmillan Nigeria Secondary Atlas, Macmillan Nigerian Publishers Ltd, Lagos

Egunyenga, E. J. (2009): Room - mate Conflicts in Nigerian Universities: Causes and Management Strategies, Department of Educational Administration and Policy Studies, Delta University, Abraka, Nigeria.

Godshall, R. (2000): Creating Communities. American School and University, 72(12), 150, 153-155.

Jiboye, A. D. (2010): The Correlates of Public Housing Satisfaction in Lagos, Nigeria, Journal of Geography and Regional Planning, Vol. 3(2), pp.017-028.

Khozaei, F., Ayub, N., and Hassan, A. S. (2010): The Factors Predicting Student's Satisfaction with University Hostels, Case Study, Universiti Sains Malaysia, Journal of Asian Culture and History, Vol. 2, No. 2.

Mabogunje, A. L. (1985): "Towards an Urban Policy in Nigeria", in Onibokun, Poju (Ed): Housing in Nigeria (A Book of Readings), Nigeria Institute of Social and Economic Research (NISER), Ibadan, p.19-35.

Morgan, D. and McDowell, L. (1979): Pattern of Residence: Cost and Options in Student Housing. Society for Research into Higher Education, Guilford, Surrey.

Ohiaghunem, E.I. (1984): Student Housing in Nigeria: An Alternative Strategy, Unpublished Seminar Paper, Department of Town and Regional Planning, Ogun State polytechnic, Abeokuta.

Onibokun, A. G. (1974): Evaluating Consumers' Satisfaction with Housing: An Application of a System Approach, Journal of American Institute of Planners, 40(3): 189-200.Onibokun, P. "Evaluating Consumers Satisfaction with Housing: A System Approach”. Journal of American Institute of Planning. AIP, May (1974).

Onibokun, A. G. (1985), Cited in Akinola, S. R. (1998): The Pattern of Housing Quality in Osogbo, Journal of Environmental Design and Management, Vol. 1, Nos. 1 and 2, pp. 109-110.

Osagie, R. O. (1993): Dropout in the University of Benin. M.Ed. Dissertation, (Unpublished) Benin: Faculty of Education, University of Benin.

PRC Report (1980): Strategies for Meeting Housing Needs in Nigeria Urban Centre. Federal Ministry of National Planning, Final Report, Lagos.

Tabet, E.M. (1971): The Accommodation of Students of the University of London. Housing Journal of the Institution of Housing Managers 6 (5): 12-13

Turner, J.F.C. (1976): Housing by the People. Marian Boyars, London. 